\title{
Framing Analysis of Anies Baswedan's Pribumi Speech in detik.com and viva.co.id
}

\author{
Nabilah Adzhani, Rahmanita Ginting \\ Master of Communication \\ University of Muhammadiyah Sumatera Utara (UMSU) \\ Medan, Indonesia \\ rahmanita_ginting@umsu.ac.id
}

\begin{abstract}
The aim of this study is to find out how viva.co.id and detik.com framed the word Pribumi in Anies Baswedan's speech. The theories used in this research are Social Media Construction Theory and Framing Analysis. The qualitative method with constructivist paradigm used in this research. Data analysis technique in this research is framing analysis of William Gamson and Andre Modigliani model. The findings reveal that detik.com and viva.co.id framed Pribumi in Anies Baswedan's speech as a great and important news to be known by public. The various framing and media point of view is presumably emerged from the media different ideologies.
\end{abstract}

Keywords-gamson and modigliani framing analysis model; detik.com; viva.co.id; pribumi; Anies Baswedan

\section{INTRODUCTION}

The virtual universe was overwhelmed by 'indigenous' discussions, starting from Anies Baswedan's first political speech after his inauguration as Governor of DKI Jakarta at the State Palace on Monday, October 16, 2017. The word 'pribumi' mentioned in the speech of the newly appointed capital of the Republic of Indonesia people call it the effort to divide the nation. This indeed starts from the political struggle for the governor of Jakarta. As we know, the opposite of Anies-Sandi is Ahok-Djarot. Where Ahok is a Chinese descendant. It is still warm in our memories, seizing the seat is not only limited to politics, election for Jakarta governor may heighten tensions. Imagine Thousands of Muslims gathered in Jakarta against Ahok, who is often referred to as non-indigenous. Viva.co.id became one of the online news portals that enliven the development of online mass media in Indonesia.

Viva.co.id has achieved one million articles on its 9th by the end of January 2018, with total followers on twitter account of 3,996,202 followers until this paper is completed. In the digital era, Viva.co.id is not the only online media that preach about the speech Anies Baswedan, one of the online media that also preach is Detik.com. The success of Detikcom contributed to the emergence of Internet fever in Indonesia in mid-1999, Detikcom still exist until now with total followers on twitter $14,841,973$ followers. On Viva.co.id recorded until this paper is completed, there are about 23 news related to Anies' speech. The news articles are still well documented on its website, while Detik.com has 66 news.

\section{LITERATURE REVIEW}

\section{A. Social Media Construction Theory}

Berger and Luckman explain that social reality by separating the understanding of 'reality and knowledge'. Reality is defined as the qualities contained in the recognized realms of being that are independent of our own will. Knowledge is defined as the assurance that realities are real and have specific characteristics. They say there is dialectic between individuals creating society and society creating individuals [1].

\section{B. Theories of In Influences on Mass Media Content}

Shoemaker and Reese (1996), in his book Mediating the Message: Theories of Influences on Mass Media Content, suggests there is a difference in meaning of an event in a media institution. There are five levels that affect the contents of a mass media. These five levels include, individual, media routine, organization, extra media, and ideology [2].

\section{Mass Communication}

A more detailed definition of mass communication was put forward by another Communications Expert, Gerbner. According to Gerbner (1967), "Mass communication is technologically and institutionally based on production and distribution of the most broadly shared continuous flow of messages in industrial societies". Gerbner's explanation, means that mass communication is the production and distribution based on technology and institutions of the continuous stream of messages and most widely owned by people in industrial society) [3].

\section{Analysis Framing}

The idea of framing was first made by Beterson in 1955 . Initially the frame was interpreted as a conceptual structure or a set of beliefs that organized political, policy, and discourse views and that provided standard categories to appreciate reality. But lately the concept of framing has been used extensively in the science communication literature to describe the process of selecting and highlighting specific aspects of a reality by the media [3].

This research uses frameless analysis of Gamson and Modigliani models. Gamson and Modigliani explain the concept that framing is a way of telling which brings constructs 
of meaning to events related to the object of a discourse. Gamson presupposes media discourse consisting of a number of interpretative packages containing constructive meanings of discourse objects. Framing analysis he developed was to understand the media discourse as a cluster of interpretive perspectives while constructing and giving meaning to an issue. Here is a model of Gamson and Modigliani framing analysis [3].

\section{E. News}

The news itself has a lot of sense. Among them is mentioned by experts who start from the world of newspapers as follows:

Paul De Massenner points out that the news is important and appealing to the public. According to Charnley and James M. Neal, the news is a report of an important, interesting, new, and important event, opinion, trend, condition, interpretation, interpretation audiences. Meanwhile, according to Sumadiria, news is the fastest report on the latest facts or facts that are true, interesting and or important for most audiences, through regular media such as newspapers, radio, television, or online internet media [4].

\section{F. Online Media}

In terms of content or content of information, presented online media in general together with print media such as newspapers or magazines, which consists of news, opinion articles, features, photos, and ads are grouped by certain categories. The content of online media is generally divided into two parts, namely pages and categories. Pages usually contain static information whereas categories contain group type groupings from the side of the topic or theme [5].

\section{RESEARCH METHOD}

The method that researchers use in this study is qualitative research with constructivist paradigm as a perspective in media research. The method used is the method of Gamson and Modigliani framing analysis, the method of analysis that sees discourse as the construction of social reality. Gamson and Modigliani framing analysis can use a constructivist paradigm approach that sees media representations in both news and articles. The framing device comprises an interpretive package containing the construction of a particular meaning namely core frames and condensing symbols.

In this study, the subject of research is Viva.co.id news portal and Detik.com. News articles related to the native words on the online news site viva.co.id and detikcom during the period of 17 October to 20 October 2017.

The unit of analysis in this study is the native word text on the speech Anies Baswedan published by Viva.co.id and Detikcom on October 17, 2017 to October 20, 2017 because: (1) The news on those date is the peak of the wording of the indigenous speech of Anies Baswedan, in viva.co.id and detikcom the intensity of the coverage of the word native is quite high. (2) There is a statement from the person who reported Anies to the authorities. This native word increasingly seized the attention of the audience because of the reporting to the authorities. Data collection techniques used in this study are: Document study (Document Research) and Library Studies (Library Research). This research uses Gamson and Modigliani framing analysis to analyze the articles of word pribumi in Anies Baswedan's speech on online news site viva.co.id and detik.com. This model is based on a structural approach that sees media representations such as news and articles, consisting of an interpretative package that contains the construction of a particular meaning. This package contains two structures, namely Core Frame and Condensing Symbol.

\section{RESUlT AND DisCUSSION}

\section{A. News from Viva.co.id}

Title: "Anies Baswedan was reported to the Police Criminal Investigation Unit by Jack Boyd"

Published: Wednesday, October 18, 2017, Author: Beawiharta

Core frames in this article direct the audience on the existence of other events resulting from the indigenous word delivered by Anies Baswedan. The Indigenous delivered Anies to the authorities.

Framing Device in this news article includes the following:

1) Metaphors: "Jack questioned the intention of the number one person in DKI Jakarta was throwing the native word". Viva.co.id uses the word Person number one to refer to Anies Baswedan. Selection of the word can certainly be associated with a position that has just received Anies as Governor of DKI Jakarta.

2) Exemplar: Exemplar in this news article is the mention of Presidential Instruction No. 40 of 2008 by Jack Lapian. With the inclusion of this Presidential Decree adding information to the reader that the native word is indeed inappropriate to say. There is a sentence "But what we know all, we must agree from INPRES No 40/2008, there is no more indigenous and non-pribumi words. But all of them are merged into Indonesian citizens.

3) Catchphrases: This article is using catchphrases in the explanation of the absence of the native word on PANCASILA delivered by Jack Lapian. "So if we mention it in Pancasila, it is also not mentioned who you are, what is your race, what is yours, what is your class. But in Pancasila we are all citizens of Indonesia.

4) Depiction: The symbol of depiction (label) is seen in a sentence that includes the word 'original'. "Jack said, honestly, based on his knowledge of history that no indigenous Indonesian natives" The use of the word 'original' in the sentence leads to something purely originating from Indonesia. Viva.co.id as if to show that none of the citizens of Indonesia is a pure person from Indonesia.

5) Visual images: In this news article, Anies Baswedan was seen taken as Governor of DKI Jakarta. The selection of this photo relates to the content of the news that discusses Anies Baswedan who was reported to the police after a 
polemic of the Natives said during his inaugural speech as Governor of DKI Jakarta.

The core frame development process is also supported by reasoning devices that provide logical reasoning in the formation of core ideas. Including the following:

1) Roots: In this article the use of roots can be found with an explanation by Jack Lapian that the reporting events to the authorities are based on their irrelevance to the Native words expressed by Anies Baswedan. "Jack Boyd said the reason for reporting Anies to the police for not accepting and offended by Anies's remarks in his speech related to indigenous and colonial Dutch colonization in Jakarta"

2) Appeals to principle: Through this news article, the use of appeals to principle tells about the history of the Jack Lapian family who is a family of BW Lapian, a hero from North Sulawesi who joined the colonists. Jack Lapian also revealed that BW lapian is the second governor of Sulawesi after Sam Ratulangi. "I happen to be a big family of BW Lapian national heroes who were awarded President Jokowi in 2015. Incidentally BW Lapian Governor of both Sulawesi after Sam Ratulangi at the time of President Soekarno. So I report, I feel offended is yes (about speech) Indigenous and non indigenous.

3) Consequences: The effect (consequences) caused by the article is that viva.co.id has succeeded in giving a view to the public that the indigenous word expressed by Anies Baswedan in his speech was fatal until Anies was reported to the authorities. In this article Viva.co.id also states article violated by Anies Baswedan. "This is referred to in article 4 letter B to 1 and 2 and article 16 of Law number 40/2008 concerning the elimination of racial and ethnic discrimination. This Police Report has been received and registered with LP / 1072 / X / 2017 / Bareskrim number dated October 17, 2017"

\section{B. Article from Detik.com}

Title: The Indigenous Speech Problem, Anies Baswedan Reported to the Police. Published: Wednesday, October 18, 2017. Author: Denita Matondang

'Core frames in this news article would like to point out the presence of a party reporting Anies Baswedan to the authorities one day after the day of his inauguration. The public gained new information again about this indigenous and heated up Through this article, found framing devices as follows:

1) Metaphors : Researchers did not find the word metaphor or parable in this article.

2) Exemplaar: "And this is a lesson for the regional head who will speak in the future no longer pronounce the existence of indigenous and non pribumi. Because behind it can very greatly lead to conflict between tribes, races, cultures, and religions, "Through the text can be seen from the view of Abdul who participated reported Anies that this should not happen again to the next leaders. Detik.com incorporated the opinion in his article also gave information to the public that the word indigenous and non indigenous can cause division.
3) Catchphrases : Through this news article, catchphrases are visible on, "This is an example of why we are raising this case so that regional heads will be able to see the case" . Researchers make the above sentence as a phrase that refers to certain thoughts and also a certain spirit. This sentence shapes the reader's mind that with this reporting can have a deterrent effect on other regional heads.

4) Depiction : "In addition, it appears to accompany Jack three members of the Banteng Muda Indonesia DPD DKI Jakarta wearing a red alma mater bearing the bull on the left side of the chest." The connotative term used is the red alma mater bearing the bull on the left side of the chest. This sentence gives meaning to the reader that red and bull are identical with PDIP which is an Anies political opponent. This is directly proportional to the fact that the Banteng Muda Community is a community that joins Ahok's victory team. Detik.com formed the perception that the one who reported Anies to the police was an Anies political opponent.

5) Visual Images: There are three visual images in this article, the first is Anies photo after the inauguration. The use of this photo forms the view that Anies reported to the police after being inaugurated. The second photo of Jack Lapian photograph that reported Anies is in bareskrim and there is also a piece of red bison uniform next to it. This implies that the cruel Jack who reported Anies was Anies's political opponent. The third picture is the contents of the Jack Lapian report. This is to inform the public what Jack Lapian reports.

The explanation of the framing devices is then supported by the patterns used in reasoning devices, among which are:

1) Roots: In this article shows a statement that conveys that Anies is guilty of violating the law mentioned in the statement. In addition, this statement also relates to the previous opinion expressed by the PSI "Currently on behalf of the Pancasila Movement reporting in connection with a criminal act that violates Law No. 40 of 2008 on the elimination of racial and ethnic discrimination allegedly committed by the Governor of DKI Jakarta was elected on October 16, 2017 during a certi fi cation session in conjunction with the PSI speech Call Speech Anies 'Devide et Impera' New Model."

2) Appeals to Principle: There is an explanation that Jack considers Anies ignoring the unity of the nation, dividing the nation. As in the sentence "Jack said the meaning of the word pribumi called Anies allegedly can divide the diversity in Indonesia. He also questioned the meaning of the indigenous Anies.

3) Consequence: The effect (consequence) in this article indicates that the consequences arising from Anies Bawsedan's speech are reports to the authorities. Detik.com frames this news as information to the public about Anies' reporting to the authorities. But detik.com added a sentence "Anies originally spoke about past colonial practice, including in Jakarta. This sentence is at the end of the article as if clarifying that allegations against Anies who violate the law is uncertain the truth. 


\section{CONCLUSION}

There are differences in framing on viva.co.id and detik.com in similarly themed articles.

Viva.co.id on the news article framed the facts of the report to the authorities by Jack Lapian to Anies Baswedan originated from the Native words expressed by Anies in his first speech. This report was caused by Jack Lapian who was offended, but this feeling of offense got support from viva.co.id by adding an article violated by Anies, as if Anies had been guilty of saying the native.

Framing built Detik.com through the article is an indigenous word that Anies disclosed to bring the authorities of his first day of office as Jakarta Governor, Detik.com more directs the reader on the article that violated Anies and the figure behind who reported Anies. The figure is linked by
Detik.com with political opposition party Anies PDIP. Detik.com also added an explanatory sentence at the end that Anies's speech by Detik.com speaks of colonization as if denying the Anies guilty.

\section{REFERENCES}

[1] B. Bungin, Sosiologi Komunikasi: Teori Paradigma dan Diskursus Teknologi Komunikasi Di Masyarakat. Jakarta: Kencana, 2008.

[2] P.J. Shoemaker and S.D. Reese, Mediating the Message in the 21st Century: A Media Sociology Perspective. New York: Routledge, 2014.

[3] A. Sobur, Analisis Teks Media Suatu Pengantar Untuk Analisis Wacana, Analisis Semiotika dan Analisis Framing. Bandung: Remaja Rosdakarya, 2004.

[4] A.S.H. Sumadiria, Jurnalistik Indonesia: Menulis Berita dan Feature. Bandung: Remaja Rosdakarya, 2005.

[5] A.S. Romli, Jurnalistik Online. Bandung: Nuansa Cendikia, 2012. 